\title{
Figures of Contrast in Tennessee Williams's Summer and Smoke ${ }^{1}$
}

\begin{abstract}
Ostensibly, Tennessee Williams's Summer and Smoke (1948) revolves around the figurative contrasts between the bodily and the spiritual. This bifurcation is the basis of the clash between the play's two main characters: John Buchanan and Alma Winemiller, whose unfulfilled romance is for Williams a study of the tragic impossibility of a conflation of opposites. In the construction of the characters, Williams shows a great deal of figurative "plasticity" - he is particular about the metaphors used to designate two sides of the central contrast. This article adopts the figurative approach to study how the playwright constructs John and Alma in metaphorical terms, as contrastive macrofigures, and to demonstrate how this figurative perspective allows him to escalate the tragedy of their impossible romance.
\end{abstract}

Keywords: Summer and Smoke, Tennessee Williams, macrofiguration, figurative contrast

"I think he can speak, / but in the language of vision"

- Tennessee Williams, The Purification

Tennessee Williams's idea of "plastic theatre" played a vital role in the early success of his dramas. The artistic goal behind the "plastic" formula was to "release the essential spirit of something that needs to be a stripping down, a reduction to abstracts" (Williams, Bak 26). In other words, Williams sought to direct his attention to the fundamental elements of artistic expression, and to shed all the obsolete practices of a realistic play. By ridding his dramas of all mimetic redundancies, Williams aimed to refashion the complex artistic formulas of the convention standardized by such playwrights as Henrik Ibsen or Seán O'Casey. At the centre of this "plastic formula" lies his "memory play," which conjoins elements of expressionism, neo-romantic emotionality and emphatic symbolism. The appropriation of various non-verbal elements of theatrical expression, like light and music, as correlative signifiers, was somewhat innovative back in the 1940s, and allowed Williams to employ the themes of deceptive illusion and nostalgic memory in a way that resonated particularly well with both readers and theatregoers.

In this creative use of theatrical plasticity, Williams did not, by any means, undervalue the role of language. On the contrary, his non-realistic setting, framed in a "plastic" and symbolic space, is meticulously described in stage-directions with the vision of a painter's eye and the verbal craft of a poet. Likewise, the exceptional literary quality of his plays springs from the dialogue that he fashions out of the natural patois of Southern American speech, an idiom that is at once rhythmical, imagistic

1 This article presents some of the results of the research grant "Hyperbole in the Writings of American Southern Authors," carried out in the Institute of English Studies at the Jagiellonian University in the years 2017-2019, financed by the Polish National Science Centre (OPUS 2016/23/B/HS2/01207). 
and genuine. It is my goal in this essay to demonstrate the way figurative aspects of Williams's language help in the construction of the dramatic space in Summer and Smoke. In particular, I wish to discuss the figurative contrasts the language of the play is so strongly saturated with, paying particular attention to metaphors and hyperbole.

\section{Macrofiguration}

In his discussion of the "poetics of mind," Raymond W. Gibbs Jr. says that "the mind itself is primarily structured out of various tropes. These figures of thought arise naturally from our ordinary, unconscious attempts to make sense of ourselves and the physical world" (Gibbs 434). The assumption that is the starting point of my discussion of Williams's figurative language in Summer and Smoke concerns precisely the manner in which the workings of the human mind are reflected in the use of metaphorical or metonymical expressions. These do not constitute mere embellishments and stylistic ornaments - in other words, they are not only "responsible for the manifestation of text as text" (Müller). On the contrary, the tropes of discourse reveal a seminal truth about the very manner in which the users of language conceptualize the reality around them that is, of their "mode of comprehension" (to borrow Hayden White's term; 1978). This constatation has considerable implications regarding the organization of the figurative language and the metafictional aspects of the language of Williams's drama.

In his Philosophy of Rhetoric (1936), written more than eight decades ago, I. A. Richards drew a distinction between two constituents of a metaphor: tenor and vehicle - the former signifies what the trope refers to, and the latter stands for the verbal phrase employed. While Richard's model of figuration concerned primarily the functioning of metaphors in the artistic context, it also reduced the significance of the complex mental process of transference accompanying the figurative language. In the Cognitive Metaphor Theory (CMT), a more dynamic and bidirectional approach, all humans "live by" metaphors that are not merely linguistic or literary devices, but effectually function as common modes of thinking. Laid out by George Lakoff and Mark Johnson (1980) almost four decades ago, CTM favours the idea of an "embodied" mind which metaphorically conceptualizes different experiential domains, mapping one domain onto another, thus forming a conceptual template that is the source of a phalanx of figurative expressions even in common, everyday language. As stressed famously by Terry Eagleton, a contemporary British literary theorist, "there is more metaphor in Manchester than there is in Marvell" (Eagleton 6). Thus, for researchers working within the paradigm of CMT, such as Peter Stockwell (2002), it is the metaphor that occupies a central role in figuration as a direct verbal representation of the workings of the artist's mind, and the way he or she conflates ideas.

In her publications on figurative language, Elżbieta Chrzanowska-Kluczewska $(2009,2010,2013)$ stresses the distinction between three diverse levels of interpretative ranks of figures in a text. The microfigurative level concerns particular phrases or clauses, and most commonly is the object of traditional stylistic analysis. The macrofigurative level involves figures which are larger and more complex, and which may span over sentences, paragraphs or even entire texts, functioning often as cohesive devices. The third level of analysis focuses on megatropes, namely, the most abstract 
and elusive figurative rank, which is concerned with the metalevel of the text and the overall directionality of thought. The figures of the metatropical level are surreptitious and remain hidden behind the two lower levels of the figuration. They would be more reminiscent of David Lodge's figurative "modes of writing" (1977). In ChrzanowskaKluczewska's model of figuration, the higher orders are constituted by various components of lower orders and the macrofigurative fabric of a text may be composed a diverse network of singular figures, not necessarily even metaphorical in nature.

The approach of figuration assumed in this essay draws on the above idea of tropes as "modes of comprehension" and the way they may function as macrofigurative devices, spanning over larger sections of texts. Such a method of enquiry allows me to look into the way in which various figures like metaphors and hyperbole, are employed by Williams to present the failed romance of the two main characters of Summer and Smoke, Alma Winemiller and John Buchanan. Furthermore, it also addresses the functioning of the body and the space in his "plastic" theatrical design. In my discussion, I wish to move beyond single tropes, and demonstrate the way particular figures constitute larger patterns of representations. In other words, I wish to construct a bridge between the microfigurative level and the macrofigurative level of analysis.

\section{Williams's Figures of Contrast}

Apart from being one of the greatest American playwrights of the $20^{\text {th }}$ century, Tennessee Williams was also one of the most prolific. His oeuvre includes an impressive collection of twenty-five full-length plays, forty short plays, two novels, numerous screenplays, an opera libretto, more than four dozen short stories and a hundred poems. Over Williams's life, his fiction underwent a profound evolution and one can see a clear caesura between the texts he authored in the 1940s and the 1950s, and those that were written in the last two decades of his life. His earlier dramas were unanimously praised by the critics and, when they entered Broadway, Williams himself was elevated to the status of artistic genius. The predominant reason for this success is that his embattled life spawned embattled fiction and the fact that most of his earlier texts - maintained in the quasi-autobiographical framework - rendered the sense of unrest and genuine pain particularly appealing. Williams's later plays, more disparaged and misunderstood by his contemporary critics, were much more obscure, especially if compared with The Glass Menagerie or Cat on a Hot Tin Roof.

For Williams's dramatic lyricism and theatrical design, the figuration of contrast seems particularly relevant. The figurative clash of concepts, not uncommonly escalated to the point of violent rupture, pervades not only his lyrical stage directions, but also the management of plot. In her recent study of Williams's drama, Annette Saddik postulates that this tendency escalated in his late texts, in the form of a "theatre of excess" (2015). Especially in his mature dramas, Williams seeks to alleviate pressures through figurative exaggeration, chaos, and laughter: "[his] excesses serve to highlight the ambiguities and inconsistencies of living in and experiencing the world - the excess that leaks out of closed systems of meaning, that seep through the cracks of the rational, the stable, the complete, and point toward the essence of the real" (Saddik 6). In consequence, Williams's "plays honor the grotesque power of chaos, of 
the irrational and inexpressible, and the truth that it reveals" (Saddik 7). The excessive and the grotesque are not only Williams's trademark ways of engaging the world, but also of escaping it.

In his Memoirs, Williams presents himself as a paragon of contradictions, in this way hinting at the conflicted nature of his fiction, which to a large extent reflects his troubled life. Among others, he famously evoked the stereotypical antitheses of American culture - a Puritan and a Cavalier - to talk about his inner conflicts: "Roughly there was a combination of Puritan and Cavalier strains in my blood which may be accountable for the conflicting impulses I often represent in the people I write about" (Williams, Waters 127). The playwright would naturally attribute the Puritan element to the overprotective and chastising upbringing of his mother, Edwina Williams, and the Cavalier to the belligerent and abusive father, Cornelius Williams. This duality translates into a notorious conflict in Williams's works in which animal promiscuity and ladylike fastidiousness clash, escalating to the point of violent rapture. This skirmish between the carnal and the spiritual translates into the conflict between the painful and disappointing present and the idealized and nostalgic past, palpable particularly in his early, "memory" plays like Glass Menagerie or A Streetcar Named Desire. The past becomes an indicator of a world that still offered hope of happiness and fulfillment, while the present, touched by decay, leaves Williams's characters to ponder desperately on what was irreversibly lost. Little wonder that Roger Boxill describes Williams as an "elegiac writer, a poet of nostalgia who laments the loss and a past idealized in the memory" (Boxill 1).

Against the background of the nostalgic drama of time, the figure of a faded belle becomes quintessential for Tennessee Williams. The framework of his drama and fiction rests on a repetitive scenario of a destructive encounter of two contrastive, archetypical characters, the faded belle and the animalistic, virulent brute. The clash between them always takes place against the background of a haunting drifter figure, whose lack of presence generates most acute discomfort and a sense of longing for the normal. William repeats this framework with a manic compulsivity, developing it in different contexts and different scenarios in the early stages of his career. Despite this artistic recycling, this broken, autobiographical template never grows old, simply because the tensions embedded in it are far too real and turbulent not to move one to the core, especially when combined with Williams's unparalleled gusto for dialogue. As stressed by Boxill, "the faded belle and the wanderer, the has-been and the mighthave-been, are elegiac characters of the 'the fugitive kind' and still-born poets whose muffled outcries are destined to oblivion the tyranny of time" (34).

\section{The Angel of Stone}

Set in Glorious Hill, Mississippi, Summer and Smoke tells the story of a doomed affair between two mismatched lovers - John Buchanan, the son of a doctor, notorious for indulging in physical pleasures and succumbing to his desires, and Alma Winemiller, a timorous southern damsel and daughter of a preacher, who embraces John's courtship, but rejects his proposal of sex. The play was released in 1948, just one year after $A$ Streetcar Named Desire, and Alma definitely ought to be included into the famous 
pantheon of southern belles from Williams's major plays - right next to Amanda Wingfield (The Glass Menagerie) and Blanche DuBois (A Streetcar Named Desire).

John and Alma are visibly designed by Williams as emblematic of contrasts set against diverse axes: art and religion contrasted with science, the carnal contrasted with the ethereal, the masculine set against the feminine - to name but a few. These macrofigurative contrasts employed by the playwright multiply and overlap, encompassing the entire meta-dramatic fabric of the play's language. It is precisely through a series of these contrastive macrofigures that Williams formulates the ontological binarity at the heart of Summer and Smoke, demonstrating the two characters' fundamental inability to synchronise their stances on life, what translates into the failure of their love.

Williams uses the strategy of contradiction right from the beginning of the play. In the prologue to Summer and Smoke, against the canvas of a "great expanse of sky" (Williams's Note on the Setting), the young John and Alma hold a flirtatious conversation by a fountain adorned with the figure of a stone angel. In his stage directions, the playwright stresses that he wishes the stone angel to be clearly perceptible - so that it would "brood over the course of the play" as a "symbolic figure." The statue of a petrified angel, an essentially contradictory image, is to constantly remind the viewers of the play that the idea of a paradox, a union of opposites is looming over the entire story of a failed romance of Alma and John.

In his Six Memos for the Next Millennium, a series of lectures for the University of Harvard, Italo Calvino, lists lightness as a "value," an asset of literary expression which will help in carrying literary works over to the $21^{\text {st }}$ century. He views the myth of Perseus, a mythological hero who "supports himself on the very lightest of things" (Calvino 10) and manages to decapitate the Gorgon, avoiding petrification and deathlike heaviness, as an allegorical image of the process of artistic creation. Calvino argues that "lightness is ... something arising from writing itself, from the poet's own linguistic power, quite independent of whatever philosophic doctrine the poet claims to be following" (Calvino 10). To the Italian writer, the subtraction of heaviness is the prerogative of art, which symbolically rises above the weight of the quotidian world. Calvino's deliberations about how lightness is emblematic of art and the liberation that comes with it perfectly translate into the metaphorical images of Summer and Smoke, especially into the dichotomy of the weight of stone conjoined with the lightness of seraphic wings.

The statue of the angel represents one of the key dichotomies of the play, namely, the contrast between soaring airiness of the form and earth-bound solidity of the matter. The image of a being associated with celestial descent is encased in a material that is heavy, dead and unchangeable. The inscription at the base of the statue reads "Eternity," a word that gives Alma "cold shivers" because of its overwhelming, soteriological implications. The angel does not change and cannot change, it is bound to "eternally" remain what it is because of the immutable material it is made of - the evanescent wings of the sculpture symbolically can never ascend. This basic figurative clash, functioning as the macrotrope for a number of longer passages in the text, allows Williams to generate figurative expressions of contrast pertaining to directionality of movement, consistency of the body, its weight and nature. Also, the "lightness" of 
Alma's singing and the spiritual components of the human nature that she notoriously emphasizes are hence, reminiscent of Calvino's "artistic" lightness. The metaphorical ascent and the lack of weight Alma hints at align with the angelic aspect of the shape of the statue - and all these elements are relentlessly brought down by the "heaviness" of the stone - whose materiality can be, in contrast, associated with the anatomy chart hanging on the wall of John's office.

\section{The Body and The Soul}

Williams describes John in the stage directions as a "Promethean figure" (Part I, Scene 1), evoking the name of the mythical benefactor of mankind who bestowed the gift of fire upon the people of the Earth. While in the myth Prometheus is mankind's kindler of the protective fire, at this stage of the plot, John fails as he cannot set the metaphorical "airiness" of Alma ablaze. In the stage directions, his character is characterized by hyperbole, a surplus of vital energy which he cannot control and which, by proxy, becomes the decisive drive behind his actions: "The excess of [his] power has not yet found a channel" (Part I, Scene 1). This figurative condensed energy, connoting increased pressure and high temperature, is shapeless and chaotic, and its boundaries are demarcated by the inside surface of his body, which is metaphorically represented as a container. As stated in stage directions, "If [the excess of power] remains without [a channel], it will burn him up" (Part I, Scene 1). John's physique is figuratively represented as a vessel which houses the shapeless, hot energy of passion. This smoke-like force is pressing upon the walls of his body from inside out with an increasing force. Thus, the failure of the body to contain the metaphorical energy inevitably generates burning tensions which, at the end of the day, stimulate his riotous behavior. The figurative increase makes him an unstable character who is driven by an excess he cannot control. In a manner typical of his style, Williams studies the motives and circumstances that compel his characters to undertake various actions, and here he manages to create an image of man who is more a passive object swayed by passions, than a active subject retaining the agency of his actions. Since his body is a metaphorical container for the energy inside of him, the carnal and the fiery become his elements - and form one part of the play's initial figurative binary.

In the figurative description of Alma, it is the air that becomes her defining element. As a singer, she bears the artistic nickname of "The Nightingale of the Delta," reminiscent of the mythical character of Philomela and of her transformation into a bird recognized for its delightful singing. Interestingly, in his Memoirs, the playwright described his frequent one-night stands as "nightingale encounters," stressing their transitory and ephemeral nature. In Summer and Smoke's stage directions, Williams stresses that in Alma's voice and manner "there is a delicacy and elegance, a kind of 'airiness" and "her gestures and mannerisms are a bit exaggerated, but in a graceful way" (Part I, Scene 1). Alma's demeanor is excessive, not unlike John's, but while he is being consumed from inside out by a surge of fiery energy, her hyperbole is that of the taciturn propriety of a southern belle. She emphatically distances herself from the summer heat of Mississippi, wishing for the Gulf wind to "cool the nights off." She finds no comfort in the pressured, combustible aura of energy that fills John's carnal 
container - instead, she wishes for air, the element she is associated with, to mitigate and temper the power of the sweltering temperate.

In a conversation, John observes that Alma is "swallowing air" and associates her hyperventilation with hysterical behavior, diagnosing her mockingly with an "irritated doppelganger." When Alma breathes heavily, she fills the metaphorical container of her body with air, the element which forms an opposition to the fiery energy that amasses in him and presses from inside out. He then teases her, by giving her a diagnosis of a "doppelganger" (Part I, Scene 1), a second self which remains hidden, and whose surreptitious presence would be connotative of a Kayserian notion of the grotesque, that is, a hidden, "alien" double who is both terrifying and uncanny. What John implies in his sarcastic assertion is that there is a fundamental dichotomy in Alma, and that her behavior is disassociated from her true nature. The way she describes herself - "My name is Alma and Alma is Spanish for soul" (Prologue) - binds her with the notions of the ethereal and the spiritual. When Alma talks of eternity, social responsibilities and propriety, John opposes her proclamations and in his reply, he resorts to carnal rhetoric, describing his dying mother in a language which pertains to the functions of a sick body and the sordid aspects of human physicality. This rhetoric, aligned with his medical education at John Hopkins Medical School, is completely alien to the artistic and spiritual language of Alma, leaving her confused and disconcerted. This dichotomy of body and soul takes its roots in the pedigree of the two characters: while John's father, as a doctor, nurses the bodies of his patients, Alma's father, as a minister of the Episcopal church, attends to the souls of his parishioners. John and Alma apparently appropriate these callings since John studies medicine and Alma performs on stage as an amateur singer. But because the two of them exist in different figurative worlds, which are derivatives of their different ontological statuses, they cannot consummate their relationship. Their romance is thwarted before it actually starts and when John later proposes sex, Alma refuses, offended by his innuendoes which cannot be reconciled with the feelings and expectations of a southern damsel. The rejection of John's proposal is the moment of rapture, of the ultimate divergence between the two characters' paths. From the metafigurative perspective, this is also the climactic moment of a metafigurative reversal which underpins the play.

\section{The Figurative Reversal}

This juxtaposition of numerous macrofigurative contrasts, emphatically stressed by Williams through a phalanx of macrofigures in the initial sections of the play, undergoes a fundamental reversal as the plot progresses. By the end of Summer and Smoke, Alma has ceased to adhere to her prescriptive decorum of propriety, while John has abandoned his belligerent and promiscuous ways and assumed the stance of righteousness, rebuffing her open advances. Using lines akin to those from the opening of the play, Alma talks of how "the Gulf wind has blown [the feeling of dying] away like a cloud of smoke" (Part II, Scene 5), instigating a powerful change in her. In consequence, as she professes, "the girl who said 'no' - she doesn't exist anymore, she died last summer - suffocated in smoke from something on fire inside her" (Part II, Scene 5). The previous content of Alma's metaphorical body-vessel turned out 
be deadly for her, figuratively depriving her of air and causing her symbolic death. Ostensibly, in her declaration, she resorts to the metaphorical language of solidity and the conceptualization of the human body as a vessel that was earlier characterized by John. This time, however, the figurative warmth and the carnal solidity become her macrometaphorical domain. The choking smoke itself is ambivalent, however, as it can be associated with both carnal passion as well as the intangibility of the incorporeal soul.

At the end of the day, ironically confirming John's mocking diagnosis, Alma's metaphorical asphyxiation is the demise of only one of the two identities that he differentiated between at the beginning of Summer and Smoke. The death of the damsel who refused his sexual advances, who constantly shivered from the cold and who was notoriously preoccupied with her social duties as a daughter of a preacher, provided the metaphorical space for the growth of her second "self." The liberated and thriving doppelganger allows Alma to shed the pretenses that were the basis of her earlier image of a belle. When the girl who says "no" is gone, by implication, it is the girl who says "yes" that is given prominence - a female version of the belligerent John, who is finally figuratively set ablaze by his earlier "Promethean" advances.

Both John and Alma are characters in transition, whose worldviews undergo a fundamental shift. John's new philosophy of life is to look beyond the carnal, and to see in the human body more than a combination of "ugly and functional" organs, as reductively implied by the anatomy chart hanging on the wall of his office. John admits to Alma, "something else is in there, an immaterial something - as thin as smoke - which all of those ugly machines combine to produce, and that's their whole reason" (Part II, Scene 5). In his newfound wisdom, he acknowledges the existence of the spiritual that permeates and overshadows the carnal, the very element that defined Alma before the transition. Likewise, his perception of Alma is turned upside down, and what he had recognized as the apprehensive "ice" of her demeanor would now be viewed by him as an inviting "flame," as her earlier refusal to embrace the physical element of human nature becomes a source of admiration for him.

Alma reacts to John's transformation with dread, declaring despondently, "you talk as if my body had ceased to exist for you" (Part II, Scene 5). She realizes that the complete reversal of John's perception of her former self effectively means that their relationship cannot come to fruition. His view of human nature is still hyperbolized, in the sense that it is still selective - yet, while at the beginning of the play John was blind to Alma's spiritual complexity, now he remains ignorant of her newly awakened corporeality. As she declares, "the tables have turned with a vengeance" (Part II, Scene 5), recognizing the dramatic irony of the situation. The reason for her earlier rejection of John is the very thing that she would like to see in him now. Thus, she realizes that getting what she had hoped for in the first place is now the reason for her ultimate unhappiness. After John's departure, in the final scene of Summer and Smoke, under the notorious, symbolic statue of the stone angel in the fountain, Alma engages in another flirtatious conversation - this time, with a nameless stranger, a "travelling salesman" that is bound to lead to a one-night stand. This conversation and the implied causal sex she becomes engaged in complete her transformation and the metafigurative reversal of the play's central binarity. 


\section{Conclusions}

The itinerary of the play, the transition from part I, "A Summer" to part II, "A Winter," provides Summer and Smoke with a timeline against which the drama of the mismatched relationship of John and Alma unfolds. And, as is usually the case in the tense world of Williams, the flow of time has a highly destructive impact on the characters of the plays. As the drama progresses, Williams reveals all the obstacles that prevent the fulfillment of the protagonists' desires. To reinforce the impact of the failed love affair upon the recipients of the play, Williams framed the tragic plot in a metafigurative act of reversal, a chiasmus-like changing of perspectives which generates the effect of a paradox. The complete rearrangement of the worldviews between John and Alma is accompanied not only by the replacement of symbols associated with them, but also by a transition in the network of macrometaphors of temperature and solidity that Williams deploys strategically in both dialogue and stage directions. These macrometaphors serve as cohesive devices, allowing him to form a uniform figurative binarity of soul and body. In the final sections of the play, Williams reverses this arrangement, demonstrating how fleeting the chance for a successful romance between John and Alma was in the first place, and how relative the monomaniac and uncompromising points may turn out to be.

\section{Works Cited}

Boxill, Roger. Tennessee Williams (Modern Dramatists). New York: McMillan Education, 1987. Print.

Chrzanowska-Kluczewska, Elżbieta. "Philosophical Underpinnings of Metaphors: Is Vico's Tropological Circe a Vicious Circle?" In Search of (Non)Sense. Ed. Elżbieta Chrzanowska-Kluczewska, Grzegorz Szpila. Newcastle upon Tyne: Cambridge Scholars Publishing, 2009. 102-114. Print.

. "Tropological Space: The Imaginary Space of Figuration." Studia Linguistica

Universitatis Iagellonicae Cracoviensis. 127 (2010): 25-37. Print.

. Much More than Metaphor: Master Tropes of Artistic Language and Imagination.

Frankfurt am Main: Peter Lang, 2013. Print.

Eagleton, Terence. Literary Theory: An Introduction. London: Routledge, 1983. Print.

Gibbs, Raymond W., Jr. Poetics of Mind: Figurative Thought, Language and Understanding. Cambridge: Cambridge University Press, 1994. Print.

Italo, Calvino. Six Memos for the Next Millennium. Cambridge: Harvard University Press, 1988. Print.

Lakoff, George, and Mark Johnson. Metaphors We Live By. Chicago: The University of Chicago Press, 1980. Print.

Lakoff, George, and Mark Turner. More than Cool Reason. A Field Guide to Poetic Metaphor. Chicago: The University of Chicago Press, 1989. Print.

Lodge, David. The Modes of Modern Writing: Metaphor, Metonymy, and the Typology of Modern Literature. London: Edward Arnold, 1977. Print.

Müller, Wolfgang G. "Style." Encyclopedia of Rhetoric. Ed. Thomas O. Sloane. New York: Oxford University Press, 2006. Web. 16 Feb 2007. www.oxford- 
rhetoric.com/entry?entry=t223.e237

Richards, Ivor Armstrong. The Philosophy of Rhetoric. New York: Oxford University Press, 1936. Print.

Saddik, Annette J. Tennessee Williams and the Theatre of Excess: The Strange, The Crazed, the Queer. Cambridge: Cambridge University Press, 2015. Print.

Stockwell, Peter. Cognitive Poetics: An Introduction. London: Routledge, 2002. Print. White, Hayden. Tropics of Discourse. Essays in Cultural Criticism. Baltimore-London: The Johns Hopkins University Press, 1978. Print.

Williams, Tennessee and John S. Bak. New Selected Essays: Where I Live. New York: New Directions, 2009. Print.

Williams, Tennessee, and John Waters. Memoirs. New York: New Directions, 2006. Print. 